\title{
THE EFFECT OF SOCIAL CAPITAL ON THE INNOVATION PERFORMANCE OF THE SMALL-MIDDLE SCALED ENTERPRISES OF AGRIBUSINESS IN BOGOR REGENCY
}

\author{
Sugara Mursid ${ }^{* 1}$, Suharno**), and Wahyu Budi Priatna**) \\ *) Master of Agribusiness Science, Faculty of Economics and Management, Bogor Agricultural University \\ Jl. Kamper, Wing 4 Level 5 Campus of IPB Darmaga Bogor 16680 \\ **) Departement of Agribusiness, Faculty of Economics and Management, \\ Bogor Agricultural University \\ Jl. Kamper, Wing 4 Level 5 Campus of IPB Darmaga Bogor 16680
}

\begin{abstract}
The aim of the research was to analyze the relationship between the social capital and innovation performance of agribusiness in Regency Bogor. The sample of the research was set as purposive sampling. There were 38 respondents involved from the nine districts. By the criteria, the entrepreneurs are also the owners of the agribusiness MSMEs and have been running their company for two years minimally. The data were analyzed by Sequal Equation Modeling Partial Least Square (SEM-PLS) method with SMART PLS 3.2.4. Based on the results, the majority of agribusiness MSMEs in Bogor Regency produce local and traditional products and have 1 to 5 employees. They earn money less than 100 million rupiahs annually, and most of them are categorized as the entrepreneurs of the micro and small enterprises. Social norm gives influence on innovation performance significantly, and it is reflected by providing aid to each other, having access to aids and willingness to share any information. The entrepreneurs of the agribusiness MSMEs possessing social norm will increase their innovation performance. Willingness to provide aid is the indicator to contribute significantly to social norm. Social network also gives effects significantly on innovation performance. Social network is reflected by network size, multiplexity and network constraints. The larger the network size, the wider important information related to the enterprises; therefore, it will increase opportunity to innovate. The height of multiplexity and network constraints will reduce the chance to innovate. Multiplexity is the highest indicator contributing to social network whereas trust variable does not give contribution significantly to innovation performance of the agribusiness MSMEs.
\end{abstract}

Keywords: MSMEs, social capital, agribusiness, innovation performance

\begin{abstract}
Abstrak: Tujuan penelitian adalah menganalisis pengaruh modal sosial terhadap kinerja inovasi UMKM agribisnis di Kabupaten Bogor. Sampel dalam penelitian ini ditentukan dengan purposive sampling sebanyak 38 responden di sembilan Kecamatan dengan kriteria pelaku usaha adalah pengelola sekaligus pemilik dari kegiatan UMKM agribisnis dan minimal telah berjalan selama 2 tahun. Data dianalisis menggunakan Sequal Equation Modeling Partial Least Square (SEM-PLS) dengan SMART PLS 3.2.4. Berdasarkan hasil penelitian, mayoritas pelaku usaha memproduksi produk olahan lokal dan tradisional, memiliki tenaga kerja rata-rata 1-5 orang, menghasilkan omset dibawah 100 juta pertahun dan sebagian besar termasuk ke dalam kategori usaha mikro dan kecil. Salah satu elemen modal sosial yaitu norma sosial, berpengaruh signifikan terhadap kinerja inovasi. Norma sosial direfleksikan oleh kesediaan saling membantu, kemudahan memperoleh bantuan serta kesediaan berbagi informasi. Pelaku UMKM agribisnis yang memiliki nilai norma sosial akan memiliki kinerja inovasi yang baik. Kesediaan saling membantu merupakan indikator yang memberikan kontribusi terbesar terhadap norma sosial. Jaringan sosial juga memberikan pengaruh signifikan terhadap kinerja inovasi. Jaringan sosial direfleksikan oleh ukuran jaringan, multiplexity dan kendala jaringan. Semakin besar ukuran jaringan maka akan memperluas sumber informasi penting berkaitan usaha sehingga akan meningkatkan peluang berinovasi. Tingginya multiplexity dan kendala jaringan akan mengurangi peluang berinovasi pelaku usaha. Multiplexity menjadi indikator yang paling berkontribusi terhadap jaringan sosial. Adapun variabel rasa percaya tidak memberikan pengaruh yang signifikan terhadap kinerja inovasi UMKM agribisnis.
\end{abstract}

Kata kunci: UMKM, modal sosial, agribisnis, kinerja inovasi

\footnotetext{
${ }^{1}$ Corresponding author:

Email: sugara.mursid@yahoo.com
} 


\section{INTRODUCTION}

The development of economy in Indonesia has started to be balanced. It does not only concentrate on macro business entrepreneurs but also on micro business ones, due to the fact that micro business entrepreneurs are relatively able to endure during the economic crisis occurring in Indonesia; moreover, they have grown up more (KMSMES Department, 2004). In this case, they are represented by micro, small and medium enterprises (MSMEs). MSMEs generally have ability to utilize local and natural resources (SDA) and to work fulltime. The resources include agricultural staple food, plantations, livestock, fisheries, trade, and restaurants. Agricultural, livestock, forestry, and fishery sectors are the business groups that significantly contribute to the structure of GDP, and the sectors are dominated by small business groups.

In 2013, MSMES amounted to 57.9 million business units or $99.99 \%$ of the total business units in Indonesia, most of which were micro scale enterprises (approximately 90\%). MSMEs' contribution reached IDR5.440 trillion to GDP reaching $60.34 \%$ of the national GDP value. They were able to absorb labor as many as 114 million people or $96.99 \%$ if it is viewed from the non-oil export performance which reached Rp 182 trillion or $15.68 \%$ of the total value of Indonesia non-oil and gas exports (BPS, 2016). Based on the data from KMSMES Department in 2012-2013, the role of MSME in National GDP by the current prices increased from IDR4.869 trillion to IDR5.440 trillion while large enterprises increased their revenue from IDR3.372 trillion in 2012 to IDR3.574 trillion in 2013 (Figure 1).

The industrial potentials in Bogor Regency are dominated by small-scaled home industries. The Department of Cooperatives and MSMEs of Bogor Regency noted that the number of MSMEs supervised by the Office of Cooperatives and MSMEs Bogor Regency increased by $142 \%$ in 2013 . The development of MSMEs shows that there is attractiveness in MSMEs for the people of Regency Bogor both as an effort to fulfill the economic needs of households as well as to manage business activities professionally. The development of MSMEs in Bogor Regency considers the potentials of the local natural resources as an area which has a geographical condition with the type of soil that is productive enough for agricultural activities (food and horticulture), plantation, and forestry. Bogor
Regency is also located adjacent to the state capital as the center of the government, services and trade with high frequency of development activities. The position provides opportunities for the development of tourism industry in Bogor Regency such as in the Peak Area located in the southern part of the regency up to the area of Ciampea located in the western part of the regency. It is a strength that can provide positive supports for the growth and development of various business activities in the field of agribusiness, ranging from upstream to downstream and various business activities outside the field of agribusiness with a scale of business ranging from small and medium scale to large scale businesses incorporated in an industry (Nurhayati et al. 2011).

If it is viewed from the existing agricultural potentials in Bogor Regency, the existence of various government programs will support the development of MSMEs and culinary tourism development programs in Bogor. The agroindustry MSMEs have the potentials to be developed in this regency. Agroindustry is industrial activities which utilize agricultural products as raw materials and design and provide equipment and services for such activities. Agroindustry can become a dominant manufacturing business and a source of income that generally provides a very significant economic role, because the agroindustry agents have the possibility to become technopreneurs or creators of the agricultural products that have added values. The agroindustry MSMEs can drive the dynamics of economy in Bogor Regency (Nurhayati et al. 2011).

The development of the entrepreneurship such as MSMEs as a form of business that has the character of entrepreneurship also plays an active role in the development of entrepreneurial characteristics. Characteristics of entrepreneurship can play a role in improving business performance (Nurhayati et al. 2011). One entrepreneurial characteristic that plays a role in MSMES is innovation. Innovation plays a role in business performance run by entrepreneurs. The characteristic of innovation is defined as the desire to always make new innovations in every work that is generally owned by MSMES perpetrators. In fact, the innovations that the MSME entrepreneurs undertake today are still largely in the modification of pre-existing ideas and not novel inventions or ideas (Nurhayati et al. 2011). Limited innovations by the business entrepreneurs will affect the ability to compete in the business world that is closely related to business continuity. The innovation implementation 
that encourages self-efficacy is important to the success of the start-up business. A successful innovation will increase the self-efficacy capacity from an individual, and self-efficacy entrepreneur affects the continuity on the conducted business (Sitepu, 2017). Integrated entrepreneurship development efforts are not solely through changes in the economic structure of agriculture but also through changes in the structure and patterns of social behavior of the community. One of them is through the empowerment of local community institutions. Social capital is defined as actual and potential number of embedded resources available and derived from networks owned by an individual or social unit (Nahapiet and Ghoshal, 1998). Elements of social capital in the society that have an important role in entrepreneurial development include social networks, social norms and mutual trust formed in the community.

Based on the theory and empirical research, social capital is believed to have a role in the development of entrepreneurship or in the scope of small and medium enterprises (MSMEs). Identification and optimization of social capital in each region in economic development have been carried out but often not accurately recorded; therefore, it is necessary to prove how much social capital can play a role in entrepreneurship development. The researchers had observed that every region in Indonesia including Bogor Regency is rich of social capital that can be used to develop entrepreneurship especially in micro and small enterprises (MSMEs), but it is still not systemically recorded. Rooks et al. (2009) mentioned in their paper, there is a relationship between the characteristics of small entrepreneurs network and their innovation performance in the context of entrepreneurship development and network which become a social capital for entrepreneurs. This social capital is a potential resource that can improve innovation performance in some conditions.

The objectives of this study were (1) to analyze the social capital that is dominant in MSMEs of agribusiness in Bogor, (2) to analyze the innovation performance which is owned by MSMEs of agribusiness in Bogor, (3) to analyze the influence of social capital on innovation performance of MSMEs of agribusiness in Bogor Regency.

Research activities included the analysis in the influence of social capital on innovation performance of agribusiness entrepreneurs in Bogor Regency. To represent the results of the research in the actual condition/phenomenon, it is necessary to collect data and information derived from the primary data and secondary data while the analyzed data were the character of social capital and innovation performance (innovativeness) owned by the agribusiness entrepreneurs of MSMEs in Bogor Regency. Observations on how to develop integrated entrepreneurship in Bogor regency were conducted.

\section{METHODS}

This research was conducted in Bogor Regency. The determination of the location was conducted purposively based on the consideration of the representation of the regions in Bogor Regency which spread over nine districts including Rancabungur, Kemang, Tamansari, Caringin, Ciawi, Bojonggede, Ciseeng, Dramaga and Parung. The study took place from October 2016 to March 2017.

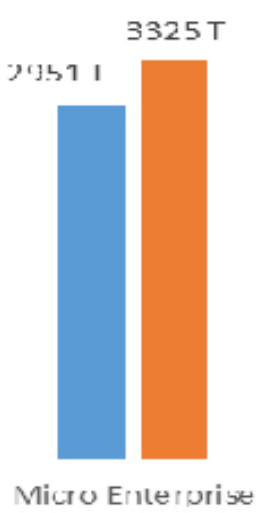

Micto Erneruribe

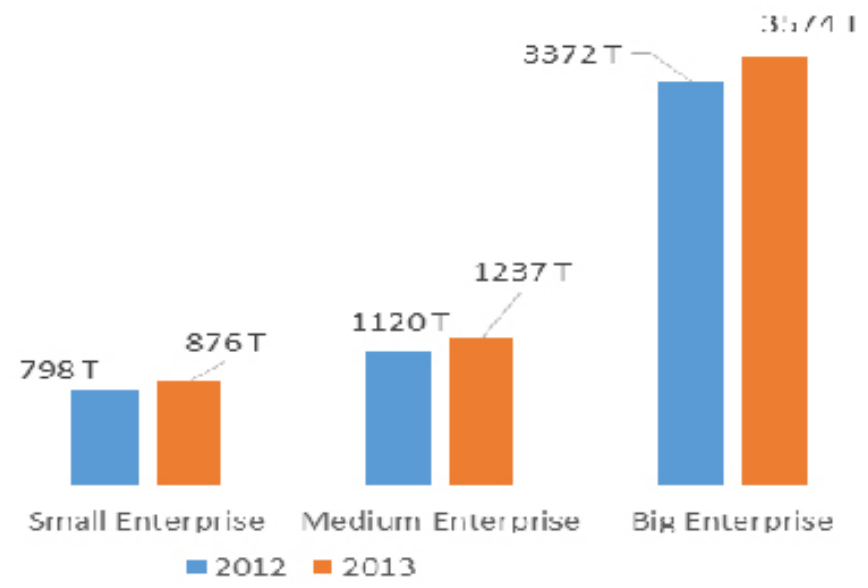

Figure 1. The contribution of MSMEs and Big Enterprises in national GDP by the current prices in 2012-2013 (Department KUMKM, 2016) 
The primary data were obtained through observations, surveys and interviews with the target respondents at the research location. The respondents in this research were selected using the purposive sampling technique. The criteria of the respondents of the agribusiness of MSMEs were those of the perpetrators of MSMEs. They included the managers and owners who had been running the business for 2 years, so that the development of MSMEs activities could be observed. In this research, 38 perpetrators of the agribusiness of MSMEs in Bogor Regency were selected as respondents. The determination of the number of these samples was based on Gay and Diehl (1992) stating that the minimum sample of the correlational research was 30 subjects. The distribution of respondent areas is presented in Table 1 . The secondary data were obtained from the related institutions with research supporting data and literature variable presented in a descriptive form.

The data collected were further processed to get the results determined as the answers of the research problem. The data were processed both qualitatively and quantitatively, and the quantitative data were processed by the method of Structural Equation Modeling Partial Least Square (SEM-PLS) analysis using Smart PLS 3 software while the qualitative data were processed descriptively. Descriptive analysis was used in this research to search for facts by interpretation of the properties of some groups of phenomena. The data were used to describe the condition of the perpetrators of agribusiness and the enterprise performance in market access, partnerships, capital and raw materials as well performance against productivity levels, and added value. The primary data were obtained through the questionnaire distribution to the respondents and tabulated in the framework of the table, and the data were analyzed to obtain the results.

Table 1. Respondent territory distribution

\begin{tabular}{lc}
\hline \multicolumn{1}{c}{ Sub district } & Number of respondent \\
\hline Rancabungur & 10 \\
Kemang & 7 \\
Bojong gede & 4 \\
Tamansari & 11 \\
Ciawi & 2 \\
Dramaga & 1 \\
Ciseeng & 1 \\
Caringin & 1 \\
Parung & 1 \\
\hline \multicolumn{2}{c}{ Total } \\
\hline
\end{tabular}

In this study, the Likert scale was used to develop a simple and easy measurement scale to measure social capital indicators and innovation performance. The final rating scale consisted of statements that stated the assessment of social capital indicators and innovation performance perceived and owned by the entrepreneurs of agribusiness MSMEs. The Likert scale used in this research amounted to five scales. The choices of the five scales included choice for 'strongly disagree' given a score or a value of one, 'disagree' of two, 'do not know' of three, 'agree' of four, and 'strongly agree' of five.

Measurement of social capital was carried out by measuring the three main dimensions of its formers related to the development of entrepreneurial skills, namely:

1. Trust. This is how much mutual trust is owned by the group members. The interpersonal aspect of trust can enhance individuals' interaction and communication among them. It is also related to institutional trust i.e. how much trust is there in the community or center.

2. Network or Associational Activities. This is closeness in a social network that positively promotes the normative environment and generates trust, cooperation, and interaction among members. Putnam (1995) mentions that a social environment based on trust, shared values, mutual support, and solidarity, has a higher level of participation in social organizations as well as a high level in social capital.

3. Social Norm or Civic Norm is the tendency of group members to cooperate and prioritize public interests above personal interests. This informal mechanism often grows with social activities because group members want to improve their social welfare so that it is more likely for them to follow group activities.

According to De Bes (2011) in Sudrajat (2013), Innovation Metrics consist of a set of tools and systems to measure the innovative capacity of an organization. These metrics can be grouped into four categories: metrics that measure innovation outcomes from an economic point of view, metrics that measure the intensity of innovation within a department and business unit or organization, metrics that measure the effectiveness of innovative activities and investments, and metrics that measure how broad the creative culture in an organization. Economic metrics measure positive and negative innovation outcomes from innovations 
that use variables from corporate financial statements, such as company sales of new products, profits from new product launches, company sales from other new product innovations. Intensity is related to the quantity of innovation without considering the results obtained. Number of patents is the number of innovations in products, services, customer experiences, and business model processes. Thus the operational thinking framework in this research is shown in Figure 2.

In this research, the data were analyzed using SMART PLS software version 3.2.4. Based on Latan and Gozali (2015), the stages of data analysis on SEM PLS are as follows:

\section{Model Specifications}

The model specification was largely run by specifying the outer and the inner models. The relationship between latent variables and indicator variables can be more easily understood by developing path diagram constructions. Structural model research in Figure 3.

\section{Evaluation of Measurement Model or Outer Model}

The convergence validity test of the reflective indicator can be seen from the individual values of the loading factor $(\lambda)$ for each construct indicator, and the critical point which is used should be $<0.5$ (Chin in Latan and Ghozali 2015). If the individual value of loading factor $(\lambda)$ does not fulfill the criteria, re-specification is conducted. It does not include the variable indicator (manifest) which has an individual value loading factor of $<0.5$. In addition, convergence validity test also sees the average variance Extracted (AVE) in which the value must be $\geq 0.5$. Restibility test uses composite reliability (CR). The critical point used to assess reliability with $\mathrm{CR}$ is suggested to be greater than 0.7 . The summary of evaluation of the model criteria in the model in this study can be seen in Table 2 .
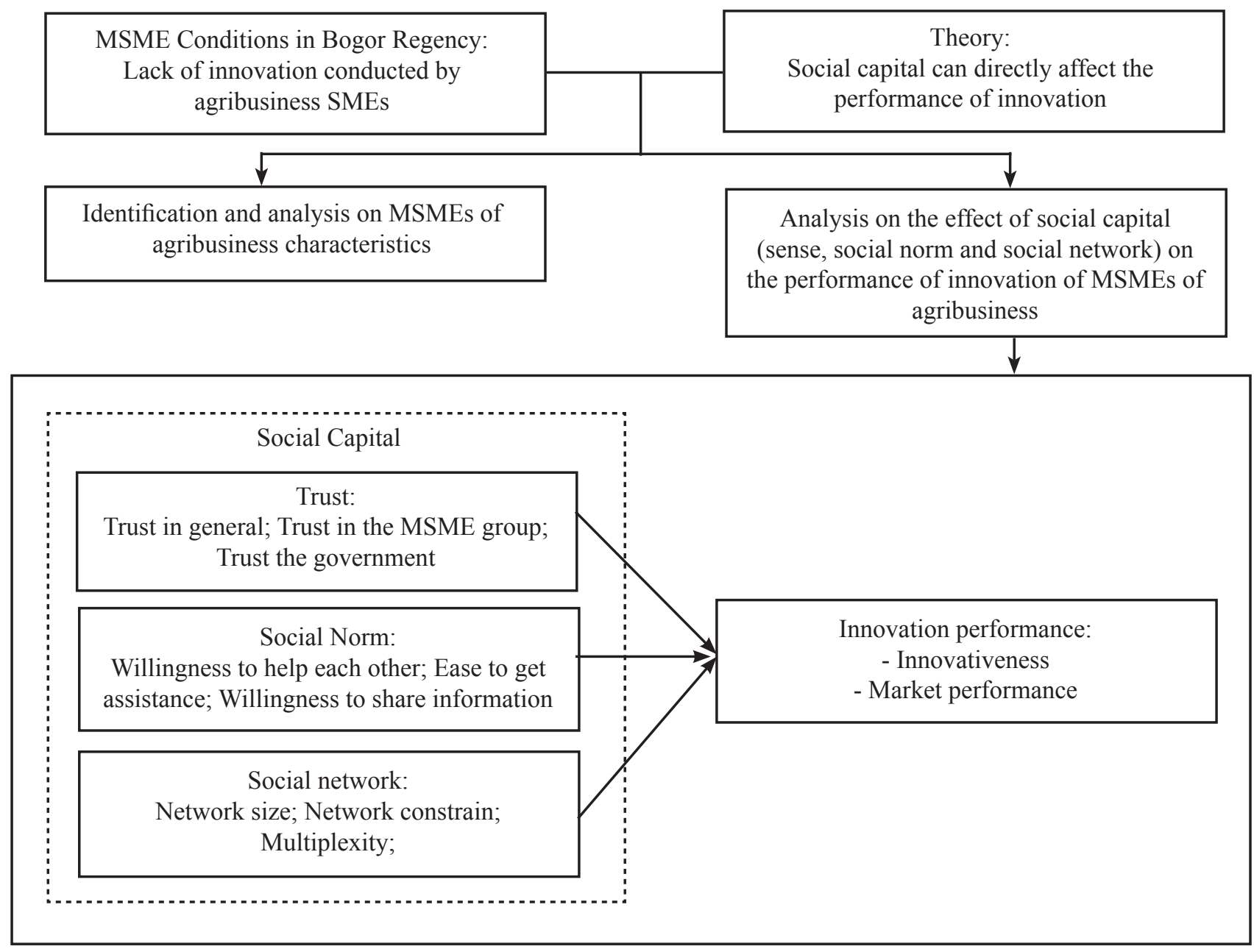

Figure 2. Research framework 


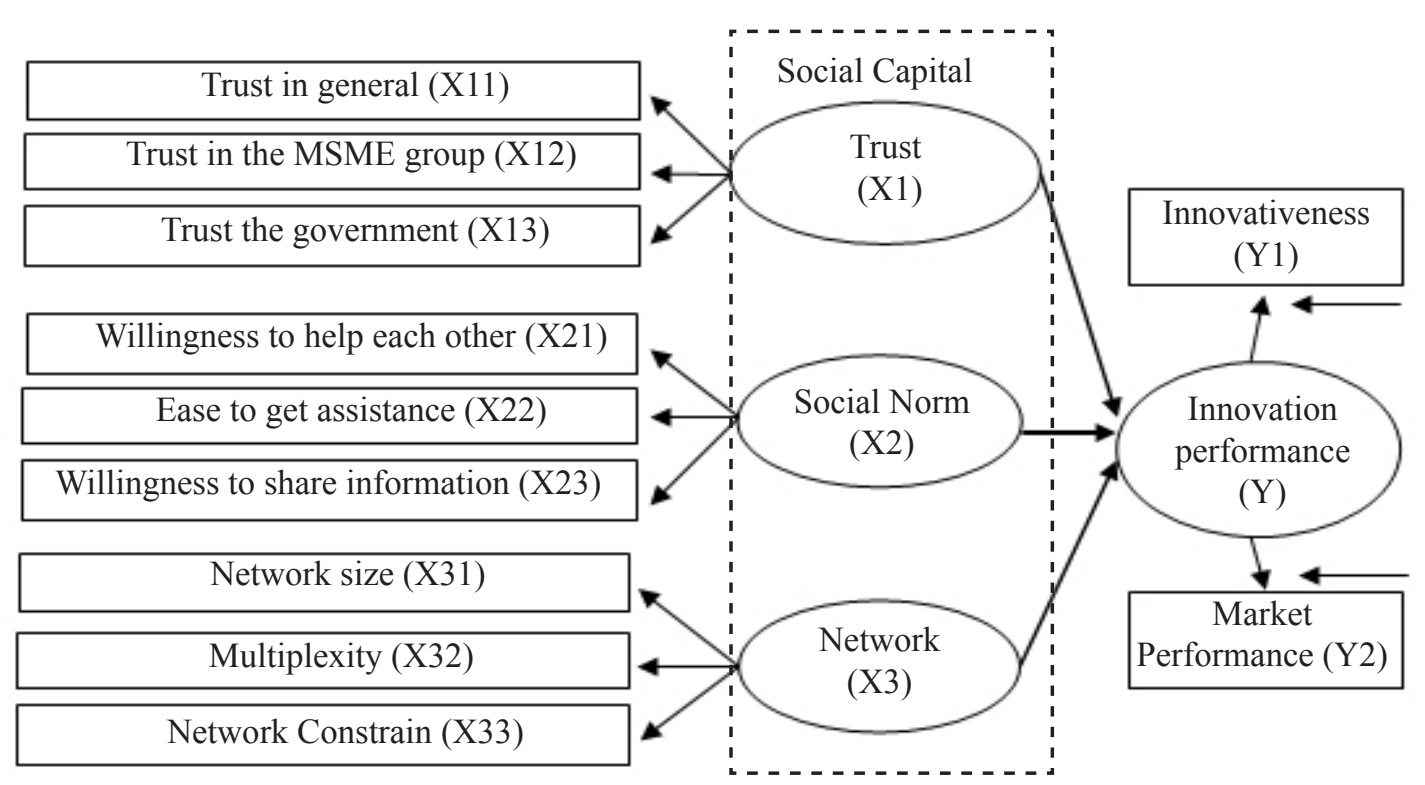

Figure 3. structural model research

Table 2. Measurement of Model Criteria of SEM PLS

\begin{tabular}{lll}
\hline Evaluasi Model & \multicolumn{1}{c}{ Parameter } & \multicolumn{1}{c}{ Rule of thumb } \\
\hline Convergen & Loading factor & $>0.5$ \\
Validity & Average Variance Extracted (AVE) & $\geq 0.5$ \\
Discriminant & Square root of AVE and the correlation between laten & Square root of AVE $>$ the correlation between \\
Validity & construct & laten construct \\
& Fornell-Larcker & Loading Score $>$ in the laten construct itself \\
Realibility & Composite reability & $>0.7$ \\
\hline
\end{tabular}

\section{Evaluation of Structural Model or Inner Model}

Changes in R-Square values were used to assess the effect of latent variables on a particular independent toward latent dependent variables whether they had substantive effects (Latan and Ghozali, 2015). In addition, the PLS model was also evaluated by looking at the Q-Square predictive relevance to see how well the observed values were generated by the model and by the parameter estimation. The summary of the structural model criteria in this study can be seen in Table 3 . The following are identification and references in the use of latent variables (exogenous and endogenous). Their manifest variables can be seen in Table 4 .

\section{RESULTS}

\section{General Description of SMEs Agribusiness in Bogor Regency}

The micro, small and medium enterprises (MSMEs) in Bogor Regency reached 773 people in 2015 while those engaged in food agribusiness were $13.5 \%$. Agribusiness in Bogor Regency is generally categorized into micro and small enterprises. MSMEs in Bogor Regency have a variety of products in their agribusiness commodities including rengginang crackers, sticky rice dodol, cassava chips, banana chips, arising chips, sentim crisps, candied nutmeg, nutmeg juice, salted eggs, processed guava and mushrooms oyster. The characteristics of the distribution of agribusiness MSME respondents in Bogor Regency are presented in Table 5. 
The micro, small and medium enterprises (MSMEs) of agribusiness in Bogor Regency have a variety of business characteristics and various agribusiness products. The majority of business actors produce some local processed and traditional products, have an average workforce of 1-5 people, generate turnover below 100 million per year and are mostly included in the category of micro and small enterprises. Perceptions of respondents based on social capital dimension indicators and innovation performance in Table 6.

The variables of trust consisted of general trust, trust to MSME group and trust to the government. Trust is a social capital owned by each individual in the form of a level of trust which is given to other individuals, MSMEs and government groups. Trust is generally intended to trust individual fellows in the community. These individual fellows included employees, in which $64.2 \%$ of the respondents strongly agreed with this. It shows that most of MSME perpetrators had a sense of trust to their surrounding. Meanwhile, some respondents $(50.9 \%)$ answered strongly agree with the confidence in the group of SMEs. Most of the MSMEs entrepreneurs believed they followed SMEs because they felt the benefits from joining MSMEs since they increase opportunities for business actors to grow and obtain other important information such as training facilities provided by the government. Beliefs in the government groups in this case referred to the Department of Cooperatives and MSMEs of Bogor District and $46.5 \%$ of the respondents had a sense of trust to the government although $5.7 \%$ of the respondents did not have the trust. Most perpetrators of MSMEs had beliefs in the Department of Cooperatives and MSMEs of Bogor District in the program of development and assistance for the entreprises.

Table 3. Structural model criteria SEM PLS

\begin{tabular}{ll}
\hline \multicolumn{1}{c}{ Model Evaluation } & \multicolumn{1}{c}{ Rule of thumb } \\
\hline R2 & $0.67:$ Substansial; 0.33: Moderate; 0.19: Low (Chin, 1998 on Ratono, 2010) \\
on & Q2 $>0$ show the model have predictive relevance and if Q2 $<0$ show that the model less in pre- \\
& dictive relevance (Stone 1974 on Latan and Ghozali, 2015). \\
GoF & $0.02:$ Low; ; 0.13: Medium; and 0.26: High (Cohen 1988 on Latan and ghozali, 2015). \\
\hline
\end{tabular}

Table 4. Latent Variable and its manifest variable

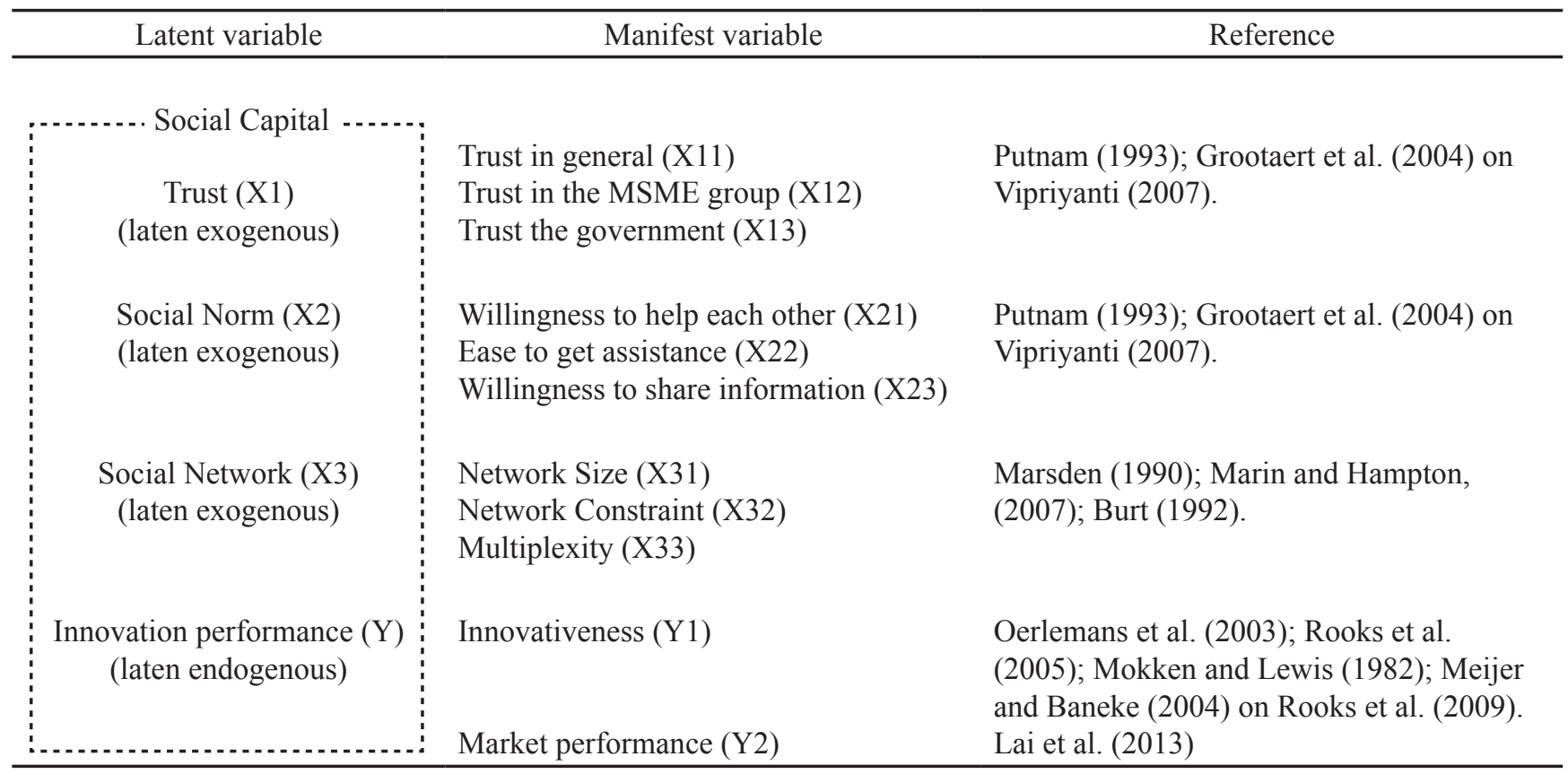


Table 5. Characteristics of respondents of MSMES agribusiness research respondents in Bogor Regency

\begin{tabular}{|c|c|c|c|c|c|}
\hline Characteristic & $\begin{array}{l}\text { Number of } \\
\text { Person }\end{array}$ & $\begin{array}{c}\text { Persentage } \\
(\%)\end{array}$ & Characteristic & $\begin{array}{l}\text { Number of } \\
\text { Person }\end{array}$ & $\begin{array}{c}\text { Persentage } \\
(\%)\end{array}$ \\
\hline Age (Years Old) & & & $2-7$ & 20 & 52.6 \\
\hline $21-30$ & 4 & 10.5 & $8-13$ & 9 & 23.7 \\
\hline $31-40$ & 5 & 13.2 & $14-19$ & 4 & 10.5 \\
\hline $41-50$ & 17 & 44.7 & $20-25$ & 1 & 2.6 \\
\hline $51-60$ & 9 & 23.7 & $26-32$ & 4 & 10.5 \\
\hline $61-72$ & 3 & 7.9 & Number of employee & & \\
\hline Gender & & & $1-5$ & 33 & 86.8 \\
\hline Male & 9 & 23.7 & $6-10$ & 2 & 5.3 \\
\hline Female & 29 & 76.3 & $11-15$ & 2 & 5.3 \\
\hline Education & & & $>15$ & 1 & 2.6 \\
\hline Elementary School & 11 & 28.9 & Omset per year (million) & & \\
\hline Junior High School & 10 & 26.3 & $\leq 100$ & 24 & 63.2 \\
\hline Senior High & 8 & 21.1 & $101-300$ & 10 & 26.3 \\
\hline Diploma/Bachelor Degree & 9 & 23.7 & $300-500$ & 2 & 5.3 \\
\hline Bussines Experience (Year) & & & $>501$ & 2 & 5.3 \\
\hline
\end{tabular}

Table 6. Perceptions of respondents based on social capital dimension indicators and innovation performance

\begin{tabular}{lccccc}
\hline \multirow{2}{*}{ Indicator } & \multicolumn{5}{c}{ Persentage (\%) } \\
\cline { 2 - 6 } & Very agree & Agree & Netral & Dis agree & Very Dis agree \\
\hline Trust & 64.2 & 20.0 & 1.1 & 4.2 & 10.5 \\
Trust in general & 50.9 & 13.2 & 33.8 & 1.8 & 0.4 \\
Trust in the MSME group & 46.5 & 38.6 & 7.0 & 5.7 & 2.2 \\
Trust the government & & & & & \\
SocialNorm & 70.0 & 19.5 & 4.7 & 5.8 & 0.0 \\
Willingness to help each other & 38.9 & 33.2 & 18.9 & 8.4 & 0.5 \\
Ease to get assistance & 60.5 & 29.5 & 4.7 & 4.7 & 0.5 \\
Willingness to share information & & & & & \\
Social Network & 7.9 & 13.2 & 23.7 & 47.4 & 7.9 \\
Network size & 15.8 & 26.3 & 23.7 & 26.3 & 7.9 \\
Multiplexity & 13.2 & 26.3 & 39.5 & 2.6 & 18.4 \\
Network Constrain & & & & & \\
Innovative Performance & 38.2 & 17.1 & 1.3 & 17.1 & 26.3 \\
Innovativeness & 62.6 & 25.3 & 6.8 & 4.2 & 1.1 \\
Market Performance & & & & & \\
\hline
\end{tabular}

The variables of social norms consisted of mutual assistance, ease of getting help and willingness to share information. The respondents who answered "strongly agree" for the indicator of willingness to help each other reached $70 \%, 38.9 \%$ was for "strongly agree" for the indicator of ease to get help, while as many as $60.5 \%$ of respondents answered "strongly agree" for the indicator of information sharing willingness. Based on these results, it indicates that most of the perpetrators of MSMEs in Bogor district are willing to help each other and find it easy to get help both from the business entrepreneurs as well as the community. In addition, most of MSME entrepreneurs are willing to share information of other business entrepreneurs related to important information in running the business i.e., technology, selling price and market. Willingness to share information from the perpetrators of MSMEs is a very important capital for the development of MSMEs business, especially in the distribution of important information that is related to the innovation of MSMEs. 
The social network variables consisted of network size, multiplexity and network constraints. Based on the measurements on the respondents, $47.4 \%$ of them had a small network size. The multiplexity shows the number of overlapping contacts on each respondent in which the higher the multiplexity, the lower the ordinal value. The multiplexity of the respondents shows that the percentage of the respondents who had high and low multiplexity values was the same i.e. $26.3 \%$ Multiplexity shows the level of diversity of contacts owned by MSMEs. If the value of multiplexity is low, the contacts of the MSME perpetrators are more diverse and vice versa. Network constraints show how many contacts owned by respondents hamper their entrepreneurial opportunity. The higher the network constraint, the smaller the entrepreneurship opportunity owned by a business entrepreneur. Based on the results of the research, most of the perpetrators of MSMEs in Bogor Regency (39.5\%) had a medium-sized network constraint.

The innovation performance variable consisted of innovativeness and market performance. Innovation performance is measured by the respondent perception by an ordinal scale. The percentage of the respondents who strongly agreed with innovativeness was 38.2 percent; therefore, it can be interpreted that most of the perpetrators of MSMEs in Bogor district had a reasonably high level of innovation/innovativeness. As much as $62.6 \%$ of the respondents strongly agreed with the market performance indicator, indicating that most of them considered the market performance of their business reasonably high. High market performance provides an illustration that the acceptance of their products by the market is quite good including their sales.

\section{Analysis on the Effect of Social Capital on the Innovation performance of MSMEs of Agribusiness in Bogor Regency with the Approach of PLS}

The influence of social capital on innovation performance of agribusiness SMEs in Bogor Regency was analyzed using Partial Least Square (PLS) analysis. It is a theoretical concept that cannot be measured or observed directly so that it requires indicator variables. This model was built with three exogenous latent variables, namely, trust, social norms and social networks and an endogenous latent variable, namely, Innovation performance. In the PLS analysis, there was an evaluation of the model output consisting of two stages, namely, the evaluations on the outer model and the inner model (Latan and Ghozali, 2015).

Based on the evaluation of the initial measurement model, it is found that the indicator variable could not reflect the construct. It can be seen that the X11 of the indicator variable (general trust) had a loading factor value $(\lambda)$ less than 0.5 , so it needs re-specification to improve the validity and reliability of the model. Model improvements can be made by issuing an indicator variable that does not meet the eligibility criteria. Display the results of the analysis on the outside model before the re-specification in Figure 4.

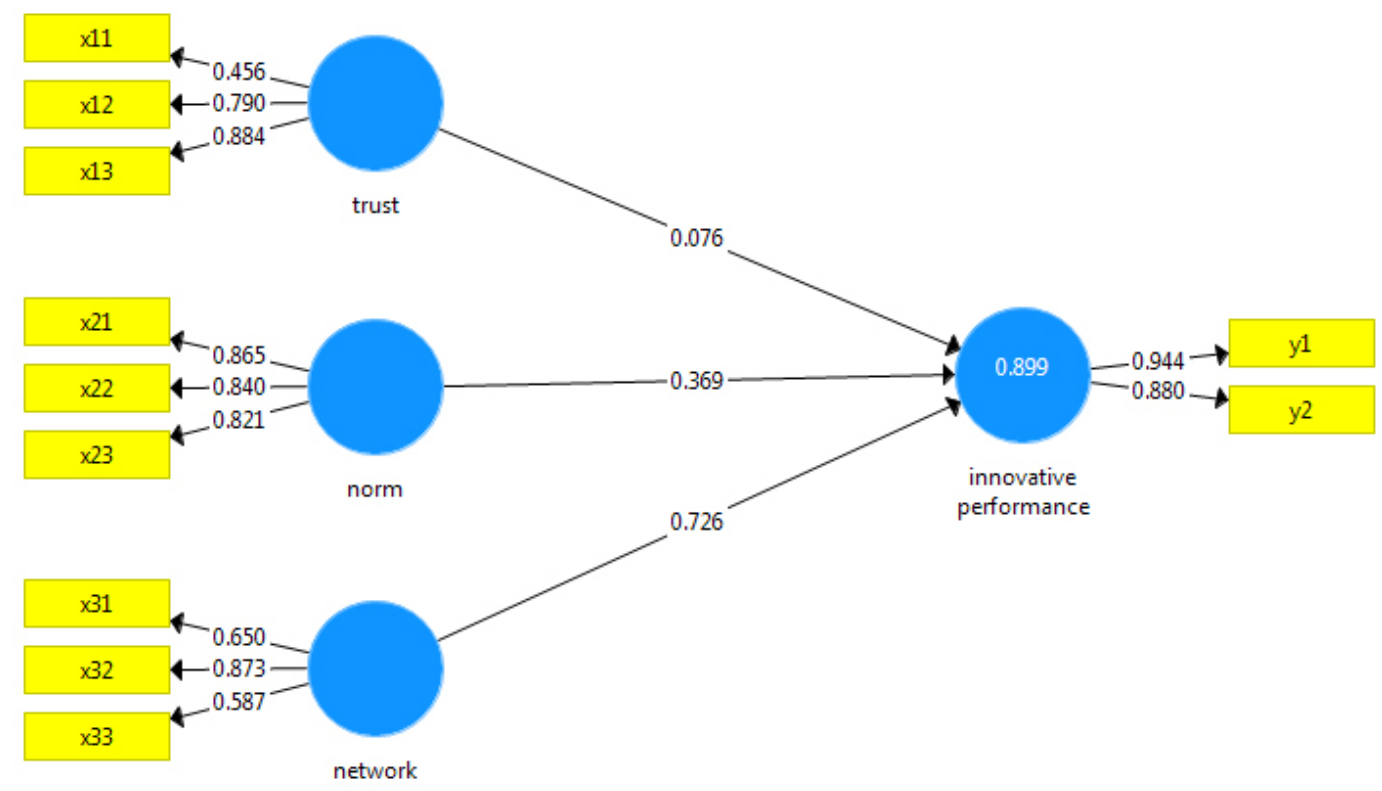

Figure 4. Display of PLS algorithm results before re-specification 
After the model was re-specified, the PLS algorithm process eventually gave the results that matched the criteria of convergence validity test on the measurement model (outer model). Display results of PLS Algorithm that have been improved can be seen in Figure 5.

Overall, the results of the evaluation of the measurement model (outer model) through the load factor analysis, Average Variance Extracted analysis (AVE) value, cross loading analysis, fornell-larcker analysis and Composite Reliability (CR) analysis can state that the research model is generalized to all objects, situations and time or it can be said that this research model is valid and reliable so that evaluation of the research model on structural model (inner model) can be done. A summary of the results of the measurement of the model evaluation is presented in Table 7.

\section{Evaluation of Structural Model (Inner Model)}

The purpose of structural model evaluation was to see the relationship between the latent construct by looking at the estimation result of the path parameter coefficient and its significance level. Structural model analysis is performed to describe the relationship between latent variables based on substantive theory of the research. The objective in this research was to see the influence of social capital on innovation performance, and it is presented in Table 8 .

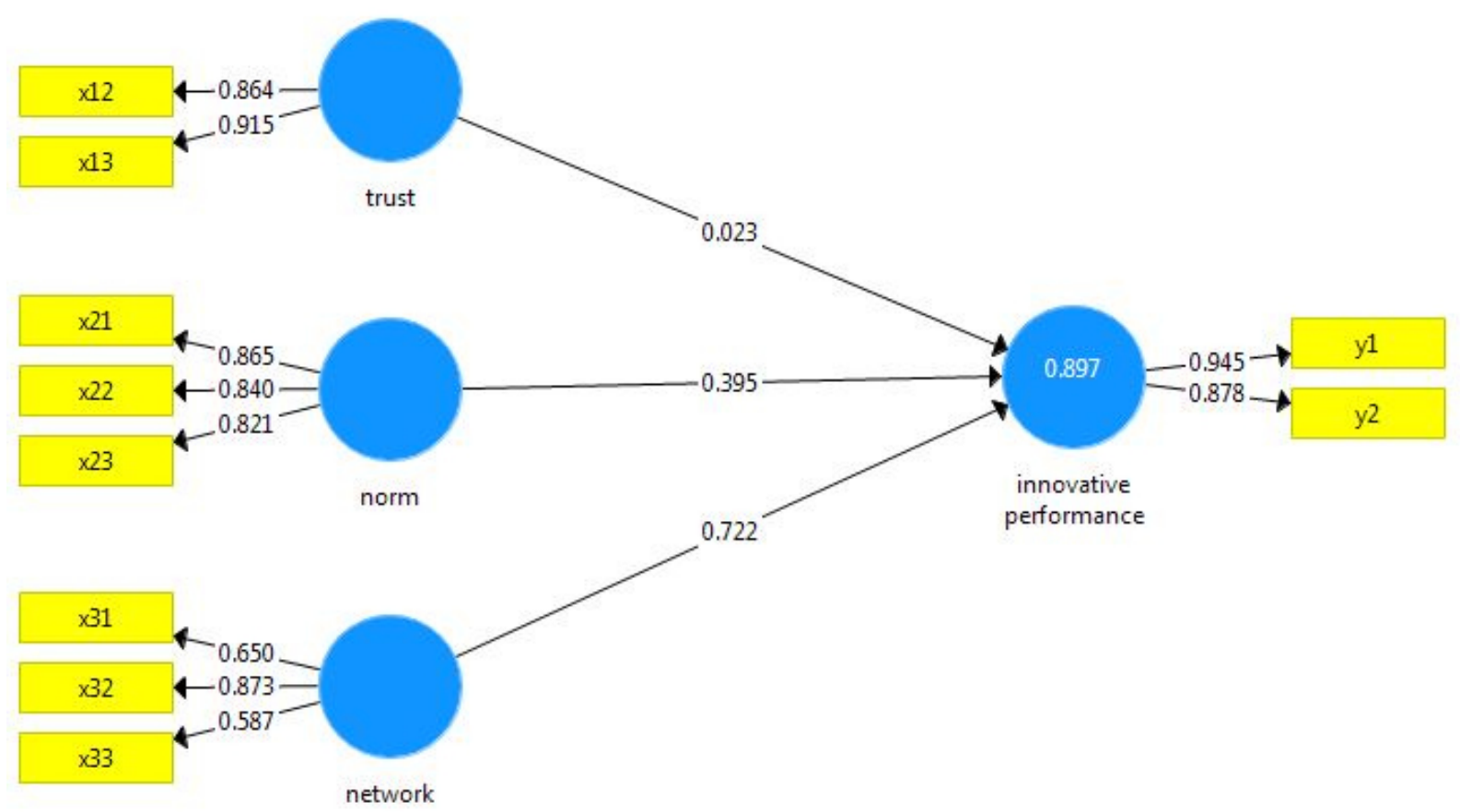

Figure 5. Display of PLS algorithm results after re-specification

Tabel 7. Loading factor, average variance extracted, and composite reliability model after re-specification

\begin{tabular}{|c|c|c|c|c|}
\hline \multirow{2}{*}{ Laten Variable } & \multirow{2}{*}{ Manifest Variable } & LF & AVE & $\mathrm{CR}$ \\
\hline & & $(>0.5)$ & $(>0.5)$ & $(>0.7)$ \\
\hline \multirow[t]{2}{*}{ Trust (X1) } & Trust in the MSME group & 0.864 & \multirow{2}{*}{$0.791 *$} & \multirow{2}{*}{$0.883^{*}$} \\
\hline & Trust the government & 0.915 & & \\
\hline \multirow[t]{3}{*}{ Social Norm (X2) } & Willingness to help each other & 0.865 & \multirow{3}{*}{$0.710 *$} & \multirow{3}{*}{$0.880^{*}$} \\
\hline & Ease to get assistance & 0.840 & & \\
\hline & Willingness to share information & 0.821 & & \\
\hline \multirow[t]{3}{*}{ Social Network $\quad$ (X3) } & Network size & 0.650 & \multirow{3}{*}{$0.509 *$} & \multirow{3}{*}{$0.752 *$} \\
\hline & Multiplexity & 0.873 & & \\
\hline & Network Constrain & 0.587 & & \\
\hline \multirow[t]{2}{*}{ Innovative Performance $(\mathrm{Y})$} & Inovativness (Y1) & 0.945 & \multirow{2}{*}{$0.832 *$} & \multirow{2}{*}{$0.908^{*}$} \\
\hline & Market performance (Y2) & 0.878 & & \\
\hline
\end{tabular}

Note: $\left.{ }^{*}\right)$ according to rule of thumb (AVE $\left.>0.5 ; \mathrm{CR}>0.7\right)$. 


\section{The Influence of Social Capital on Innovation performance}

This social capital is a potential resource owned by individuals and networks that can improve innovation performance. Social capital is represented by three variables of trust, social norms and social networks. The effect of social capital (trust, social norm and social network) on innovation performance can be seen and analyzed by structural approach through the hypothesis test. Hypothesis test or significance test is a test of significance of relationships between constructs that are used as a basis in conducting hypothesis testing. This test can be seen from the value of statistical significance above the t-table ( $\alpha 0.05$; $\mathrm{t}$-table 1.96).

Overall, a summary of structural model analysis results that illustrates the influence of social capital (trust, social norms and social networks) on the innovation performance of MSMEs of agribusiness in Bogor Regency can be seen in Table 9.

\section{The Influence of trust variable on Innovation performance}

The result of significance test showed that hypothesis one (H1) was rejected i.e. trust variable had no positive effect and was not significant to innovation performance variable with result of the $t$ test of $0.023>1.96$. The indicator of trust is not enough to give a real effect on innovation performance. This result is different from the research conducted by Humaira (2011) stating that indicators of trust have a real effect on the entrepreneurial characteristics of micro business actors in Dramaga District Bogor. Similarly, the research conducted by Vipriyanti (2011) revealed that indicators of trust had a real effect on the economic development of households and regions in Bali. This shows that trust have a large contribution to social capital but does not have a real effect on innovation performance. The indicator of trust is not enough to give a real effect on the performance of this innovation because of the level of public trust between individuals, groups of MSMEs and the government that does not always increase or can be said to have a downward trend. The results of the research on the community view on the level of mutual trust in the community environment are presented in Table 10.

Based on Table 10, the perception of the people related to the mutual trust among the population decreased by 47 percent. Mutual trust decreases where the level of mutual suspicion between people increases slowly. It will reduce the value of trust owned by the society in which it is the value of social capital itself. In addition, based on the results of the study, there were some business entrepreneurs who did not join the MSME groups because the groups did not give a real role in the development of their business, and they found difficulties to get help through the MSME groups, especially for financial assistance. This shows that each region has its own uniqueness in the character of its community that can provide value of social capital in the area. Lyer et al. (2005) states that the different characteristics of the region or community are closely related to the built social capital. People in certain areas are able to build strong social capital (bridging social capital) while others are able to build bonding social capital.

Table 8. Evaluation of structural model (inner model)

\begin{tabular}{llcc}
\hline \multicolumn{1}{c}{ Model Evaluation } & \multicolumn{1}{c}{ Rule of thumb } & Result & Information \\
\hline R2 & $0.67:$ Substancial; 0.33: Moderate; 0.19: Low & 0.897 & substancial \\
on & $\begin{array}{l}\text { Q2 }>\text { 0 the model predictive relevance; jika Q2 }<0 \\
\text { the model lees in predictive relevance }\end{array}$ & 0.897 & model predictive relevance \\
GoF & $0.02:$ low ; 0.13 : medium; dan 0.26: high & 0.799 & High compatibelity of model \\
\hline
\end{tabular}

Table 9. Results of model significance test after re-specification

\begin{tabular}{lccc}
\hline \multicolumn{1}{c}{ Hipotesis } & Original Sample & T statistic & Information \\
\hline Trust $\rightarrow$ Innovative Performance & 0.023 & 0.352 & Not significant \\
Social Norm $\rightarrow$ Innovative Performance & 0.395 & $4.931^{*}$ & Significant \\
Social Network $\rightarrow$ Innovative Performance & 0.722 & $11.506^{*}$ & Significant \\
\hline
\end{tabular}


Table 10. Perceptions of respondents to the level of trust among residents

\begin{tabular}{lc}
\hline \multicolumn{1}{c}{ Perseption of respondent } & Persentage (\%) \\
\hline Increasing & 26 \\
Netral & 26 \\
Deminishing & 47 \\
\hline
\end{tabular}

Mutual trust is a core concept in social network research, and trust even becomes more important than social capital structure. It shows that if the perpetrators in the network do not trust each other, no matter how high the ownership level and amount of network congestion, they will not share valuable information to help each other (Yu and Junshu, 2013). Mutual trust in a group is usually higher and trust can help group members to embrace different perspectives. This will help group performance such as creativity and innovation (Qinxuan et al. 2013). Besides mutual trust, another important attribute of the group is vision or view sharing that can help motivate group members and integrate differences in knowledge and experience that indirectly can develop group performance (Rickards et al. 2001).

However, mutual trust does not always provide benefits. In a network with a high level of trust, each individual has a high depression/pressure if they have a direct and indirect relationship that provide pressure symptoms (Rosenquist et al. 2011) while some studies show a non-significant relationship of mutual trust (Fujiwara \& Kawachi, 2008). Although the results of trust are inconsistent, most researchers have shown that trust is the basis for a network. The effects of individuallevel trust in general are positive, such as information, experience, and knowledge sharing (Vathsala and Purnima, 2011; Adler and Kwon, 2002).

\section{The Influence of Social Norm Variables on Innovation performance}

The result of significance test showed that hypothesis one (H1) was accepted, indicating that the social norm variable had a positive and significant effect on the innovation performance variable with result of $t$ test of $0.395>1.96$. This shows that the variable of social norm gives a real effect on innovation performance of agribusiness actors in Bogor Regency. Social norms have a noticeable contribution especially in developing regions (areas with low GDP) and social norms will play a major role in controlling the growing forms of behavior in the society (Vipriyanti, 2011). Definition of the norm itself is a set of rules that are expected to be followed by members of the society in a particular social entity. These norms are usually institutionalized and contain social sanctions that can prevent individuals from doing something that deviates from the habit. Collective rules are usually not written but understood by every member of the society and they determine the expected behavioral patterns in the context of social relations (Brata, 2004). This makes social norms have a significant effect on innovation performance because people consider social reasons and participation in the community. Also, they consider the social sanction they will receive if they do not participate in community activities. The willingness to help each other, ease of obtaining assistance and willingness to share information among fellow business actors or with fellow communities provide a very important role where the flow of information and business needs can take place well to improve the innovation and business performance of every business actor.

\section{The Influence of Social Network Variables on Innovation performance}

The result of significance test shows that hypothesis one (H1) was accepted, indicating that the social network variable had a positive and significant effect on innovation performance variable with the $t$ test result of $0.722>1.96$. This shows that the social network variable significantly affected the performance of innovation. Social network is a capacity owned by each individual related to the number of contact rate overlap relationships and network constraints.

Every business actor who has a wide network is likely to get greater benefits from this extensive relationship. Based on the connecting and bonding theory, a person within a group can have the same resources with other members, but with relationships with other groups, the person will be able to access different resources, and this may benefit the individual (Granovetter, 1985) and the success of one's career (Podolny and Baron, 1997). It can enable every business actor to develop his business and innovation based on the great amount of information received.

In addition, the MSME group plays a role in the flow of information and technology gained by fellow group members. Each member of the group will share information obtained during the training to other 
members of the group. They need strength of good internal group relationships so that the process of information distribution can work well. Strong links are the basis of trust which can enhance the transfer of high quality information known as unspoken knowledge (know the same know) (Francesc Xavier MolinaMorales et al. 2010 in Yu and Junshu, 2013). However, there are disadvantages of strong links, for example, strong links may not obtain different information or resources (Burts, 1992).

Network has many advantages for business actors such as network size. Business actors are able to widen their network to get important information and human resources owned by the network partner. The next step is how business actors put their position in social network to find out the shortcut to gain information they need. (Granovetter, 1973 in Salaff and Greeve, 2009).

Network constraint is defined as how big the obstacle that they own in their contacts. Business actors who have wide network sizes will likely have network constraints as well because, in general, business actors in the network always have some valuable resources for other actors. Business actors exchange information either by sending or receiving it. It is also commonplace in the network that some of the perpetrators cannot get valuable resources but need to provide some valuable resources such as sharing valuable information and providing some good work. These networks are often created and processed by fraternal relationships, friendships or emotional affiliations. However, at the organizational level, social relations are considered as a whole. Thus, the acquisition or loss of individual actors is not considered within the organizational level (Yu and Junshu, 2013). There is a difference between the effects of social capital on the individual level and on the organization level. Group members usually have connections with almost every member of the group, and each level of members and concentration is usually very high, given a group as a network, the network density is usually very high and the ability of the group members of the corporates with others can improve the overall performance of an organization (Marks et al. 2001; Vishal et al. 2011). In this case, the social capital structure is positively related to group performance. There is a relationship among individuals, group capital structures and knowledge sharing in groups that make up the non-linear U curve (Yan et al. 2013).

\section{Managerial Implication}

Managerial implication is based on performance evaluation of social capital indicator which will improve the innovation performance of MSME agribusiness in Bogor Regency. The presence of strong social capital in the network increases the efficiency of network actions, reduces the possibility of opportunism and reduces the need for costly oversight processes. This is a needed requirement to produce significant benefits for the companies as they enter the market, both domestically and internationally. Small entrepreneurs accumulate social capital in networks that support them pursuing growth opportunities, including internationalization. Information, knowledge and resources that may be useful in exploring foreign markets are generally derived from the formal and informal contacts that entrepreneurs build outside of their organizations. In an intercompany network, the competitive advantage of each company is related to the advantages of the network in which the companies are embedded, because relationships can provide valuable rents for both network and member companies. However, the creation, maintenance and development of social capital in the network are expensive tasks. The process of establishing and utilizing social capital requires investment and time (Antoldi, 2011). Therefore, the existence of managerial implications is expected to increase the value of social capital that can improve the performance of innovative MSME agribusiness in Bogor Regency. Indicators evaluated were derived from social capital variables fragmented by three indicators of trust, social norms and social networks that have a significant effect on innovation performance of agribusiness SMEs in Bogor Regency.

Based on the results of Structural Equation Model Partial Least Square (SEM PLS) analysis, social norms and social network variables were significant variables affecting the innovation performance of agribusiness MSME in Bogor Regency while the variable of trust did not have an significant effect on the innovation performance of MSME agribusiness in Bogor Regency. The social norm variable consisted of several indicator variables i.e. mutual assistance, ease of getting help and willingness to share information. Based on the results of the analysis, social norms had a significant effect on the innovation performance. In other words, the perpetrators of SMEs need to improve the values of social norms in running their business that is by increasing willingness to help each other, willingness 
to share information with other SME actors in an effort to improve the performance of SME innovation performance in Bogor District. The social network variables consisted of several indicator variables, namely, network size, multiplexity and network constraints.

Based on the results of the analysis, social networking variables significantly influenced the performance of innovations. In other words, the perpetrators of MSMEs need to increase social network in running their business by increasing the network size, reducing multiplexity and network constraints by varying relationships, and establishing communication network for more diverse information in an effort to improve the performance of MSME agribusiness innovation in Bogor regency. Based on the results of the analysis (SEM PLS), trust variables consisting of variable indicators of trust in general, trust to group of MSMEs and belief to the government that had no significant effects on the innovation performance of MSMEs agribusiness in Bogor Regency. In other words, the trust of MSME perpetrators to other business actors, MSME and government groups had no significant effects on innovation performance as long as the perpetrators of MSMEs run social norm values in running their business and have wide and diverse social network.

\section{CONCLUSIONS AND RECOMMENDATIONS}

\section{Conclusions}

The social capital of agribusiness actors in Bogor Regency is reflected by trust, social norm and social network. Trust to the government is the highest indicator that contributes to trust. The willingness to help each other is an indicator that gives the greatest contribution to social norms. Multiplexity is the most contributing indicator of social networking. Innovation performance is reflected by innovation/innovativeness and market performance. Innovativeness is an indicator that gives the greatest contribution to innovation performance.

Social norms have a significant effect on innovation performance. Social norms are reflected by the willingness to help each other, the ease of getting help and the willingness to share information. The perpetrators of agribusiness SMEs who have social norms value will improve the performance of innovation. Social network also gives significant influence to the performance of innovation of MSMEs in Bogor Regency. Social networks are reflected by network size, multiplexity and network constraints. The large size of the network will expand important sources of business-related information that will increase the chances of innovation. The high multiplexity and network constraints will reduce the chances of innovating business actors.

\section{Recommendations}

The perpetrators of agribusiness MSMEs in Bogor Regency should apply the values of social norms in running their business such as helping each other and sharing important information with other fellow business actors, so that innovation performance can increase. In addition, it facilitates the process of providing assistance to business actors in order to form a positive social norm in running the business.

The perpetrators of agribusiness MSMEs need to expand the business network by following the communities of entrepreneurship or entrepreneurship training and make the most of the role of MSMEs group. MSME group should also increase information sharing activities within the membership in order to improve the quality of information received and update it for their members.

\section{REFERENCES}

Adler PS, Kwon SW. 2002. Social capital: prospect for a new concept. The Academy of Management Review 27: 17-40.

Antoldi F. 2011. Strategic Networks, Trust and the Competitive Advantage of SMEs. XIV: 23-42.

[BPS] Badan Pusat Statistik. 2016. Buku Statistik Indonesia. Jakarta: BPS Jakarta.

Burt RS. 1992. Structural holes: The social structure of competition. Cambridge, MA: Harvard University Press.

Brata AG. 2004. Nilai Ekonomis Modal Sosial pada Sektor Informal Perkotaan. Jakarta: Lembaga Penelitian Universitas Atma Jaya.

Fujiwara T, Kawachi I. 2008. A prospective study of individual-level social capital and major depression in the United States. Journal of Epidemiology \& Community Health 62: 627633. https://doi.org/10.1136/jech.2007.064261.

Gay LR, Diehl PJ. 1992. Research Methods for Bussiness and Management. New York: 
Macmillan Publishing Company.

Granovetter MS. 1973. The strength of weak ties. American Journal of Sociology 78: 1360-1380. https://doi.org/10.1086/225469.

Granovetter M. 1985. Economic action and social structure: the problem of embeddedness. American Journal of Sociology 91(3): 481-510. https://doi.org/10.1086/228311.

Humaira R. 2011. Peranan modal sosial dalam pengembangan nilai kewirausahaan (Kasus Pedagang Kecil dan Anggota Kelompok Tani di Desa Cikarawang Kecamatan Dramaga Kabupaten Bogor) [skripsi]. Bogor: IPB.

Latan H, Ghozali I. 2015. Partial Least Square Konsep, Teknik dan Aplikasi Menggunakan Program SmartPLS 3.0. Semarang: Penerbit Universitas Diponegoro.

Lyer S, Kitson M, Toh B. 2005. Social Capital, Economic Growth, and Regional Development. Regional Studies 39(8):1015-1040. https://doi. org/10.1080/00343400500327943.

Marks MA, Mathieu MJ, Zaccaro SJ. 2001. A temporally based framework and taxonomy of team processes. Academy of Management Review 26: 356-376.

Nahapiet J, Ghoshal S. 1998. Social capital, intellectual capital, and the organizational advantage. Academy of Management Review 23: 242-66.

Nurhayati P, Sarianti T, Daryanto HK, Muflikh YN. 2011. Analisis Pengaruh Karakteristik Kewirausahaan Terhadap Kinerja Wirausaha Pada Unit Usaha Kecil Menengah (UKM) Agroindustri Di Kabupaten Bogor. In: Prosiding Seminar Penelitian Unggulan Departemen Agribisnis 2011.

Podolny JM, Baron JN. 1997. Resources and relationships: social networks and mobility in the workplace. American Sociological Review 62(5): 673-693. https://doi.org/10.2307/2657354.

Putnam R. 1995. The Prosperous Community-Social Capital and Public Life. America.

Qinxuan Gu, GregG W, Lihong W. 2013. Social capital and innovation in R\&D teams: the mediating roles of psychological safety and learning from mistakes. R\&D Management 43(2): 89-102. https://doi.org/10.1111/radm.12002.
Rickards T, Chen MH, Moger S. 2001, Development of a self-report instrument for exploring team factor, leadership and performance relationship. British Journal of Management 12(4): 243-250. https://doi.org/10.1111/1467-8551.00197.

Rooks G, Szirmai A dan Sserwanga A. 2009. Social Capital and Innovative Performance in Developing Countries The Case of Ugandan Entrepreneurs. Paper 7th Globelic conference on Inclusive Growth, Innovation and Technological Change Dakar, Senegal,Vol 22: 1-27, October 2009.

Rosenquist JN, Fowler JH, Christakis NA. 2011. Social network determinants of depression. Molecular Psychiatry 16: 273-281. https://doi.org/10.1038/ mp.2010.13.

Salaff, Greeve. 2009. Social capital and entrepreneurship. Entrepreneurship, Theory \& Practice 28(1): 1-22.

Sitepu SNB. 2017. How innovation encourages self eficasy to support business start up success?.Indonesian Journal of Business and Entrepreneurship 3(2).

Sudrajat D. 2013. Kapabilitas dinamik, kinerja inovasi dan kinerja perusahaan jasa logistik di Indonesia. Jurnal Bina Nusantara 5(1):798-811.

Vathsala W, Purnima W. 2011. Benefits gained from dimensions of social capital: a study of software developers in Sri Lanka. Information Technology \& People 24(4): 393-413. https:// doi.org/10.1108/09593841111182287.

Vipriyanti NU. 2011. Modal Sosial dan Pembangunan Wilayah. Malang: UBPress.

Vishal K. Gupta RH, Ali AY. 2011. Social capital, collective transformational leadership and performance: a resource-based view of selfmanaged teams. Journal of Mangerial XXIII(1): 31-45.

Yan Y, Jin-Xing H, Xiao YD, Mohamed K. 2013. A multilevel model for effects of social capital and knowledge sharing in knowledgeintensive work teams. International Journal of Information Management 33: 780-790. https:// doi.org/10.1016/j.ijinfomgt.2013.05.005.

Yu C, Junshu D. 2013. A literature review of the effects of social capital-from the personal network perspective. International Journal of Business and Social Science 4(12):251-257. 